\title{
Recording the last trance: a case of communication with invisible creatures from Eastern Serbia
}

\author{
MARIA VIVOD \\ Centre National de Recherches Scientifiques, Strasbourg, France \\ vivod@hotmail.com
}

DOI 10.11606/issn.2316-9133.v29i2pe179727

\section{Introduction}

In early spring of 2015 while working as a researcher of the EU-founded research project 'Vernacular religion on the boundary of Eastern and Western Christianity: continuity, changes and interactions ${ }^{11}$ for the University of Pécs, Hungary I travelled to Eastern Serbia in a quest of women communicating with invisible creatures (spiritcommunicators).

The mission initiated by a short video footage published on Youtube by a local ethnographer made a decade earlier. The video (since then deleted) was about a woman from a small village of Topolnica who was singing and dancing in trance and was communicating with invisible creatures. The video was called 'Šojmanka'. Šojmanka [shoymanka] being a little-known expression from the Vlach ${ }^{2}$ language and I immediately recalled a groundbreaking paper published 60 years earlier about a phenomenon which was declared as "vanished since".

That famous paper, published in 1950 by a Yugoslav ethnographer Persida Tomić brings us detailed description of the fairy-seeing phenomena from Central Serbia by the ethnic minority of 'Vlach Gypsies' (vlaški cigani). This author was the one who used first the expression of 'šojmanka' among other expressions ('sojmanose', 'vilarka'). The paper with this substantive is later mentioned in the book of Zoran Čica (2002) about the phenomenon of fairy-seeing individuals from a historical perspective. In both cases, Tomić and Čiča did not dwell on the signification of the Vlach term 'šjmanka'.It was taken as if this were a Vlach term of the same 'fairy-seeing' phenomenon. Tomić provides a detail account of fairy-seeing related events that she had the occasion to observe in 1946/47. She starts with a description

\footnotetext{
${ }^{1}$ FP7-IDEAS-ERC Project Reference: 324214

2 The Vlachs are the Balkan Romance-speaking group living south of the Danube in what are now eastern Serbia, southern Albania, northern Greece, North Macedonia, and southwestern Bulgaria
} 
of the main characteristics of a šjmanke (P1.): women who fall regularly into trance of specific days in a year.

After seeing the clip, I have managed to establish a contact with its author who helped me to locate the woman on that video. I received even her phone number, and although the initial conversation was pretty difficult -partially due to the noise in the bad phone-line, due to her hesitant use of the Serbian language - I found out that her next 'fall' (as she called it) was to be soon and that it will be the last one: she was turning 60 years old in a year, and the fairies do not communicate with women more than 60 .

\section{The fairy-seeing phenomenon}

Ivanka (1956) is a Vlach farmer woman from eastern Serbia, living in an isolated farm with her husband and a grown-up son on the top of the mountain called Pojenj near the village of Kulma Topolnica. She has three children and was married twice. Her first husband has left her and according to her words and 'disappeared'. The disappearance of her husband coincided with her initiation into the world of her 'sisters'. In spite of her being a šjmanka or a padalica (a Serbian term used in the region to describe Ivanka's ability to fall into trance, hence the expression the 'fall') she managed to marry a second time, at her 'great surprise' at she says. Her initiation happened when she was about 20-21 years old. She was found by her mother-in-law on a top of a pear-tree. She was oblivious of herself. She was singing on the top of that pear tree. She describes the creatures that she has continued to see on regular basis as beautiful young long-haired (blond) women dressed in white. She also named them as: Sinziana, Maria and Majka Prečasa. They appear to her on specific days and speak to her, than she has to transmit their messages and instructions to the living. She tried to avoid her 'sisters' at the beginning: she hid herself in the stack of hay in order to escape them but as she says these creatures always managed to find her, punished her physically and brought her back on a top of a pear or cherry tree. These creatures punished her transgressions or her avoidance by taking away her voice, paralyzing her or beating up her. She says that she hard blue marks on her body from the beatings of these creatures. As she says: "[she] had to obey them". In her 'fall' - as she calls the state in which she is oblivious of herself and the [human] world around her, she sees the world of these creatures: beautiful pastures and fields covered with flowers. She has a particular song she sings every time in order to put herself in a state of trance: "In a field covered with flowers I climb, climb, with my sisters on the Krš [a mountain in the region?”. In a field covered with flowers I go down with my sisters to the pear tree; my sisters make me climb the pear tree. And they are young, my sisters. In a field covered with flowers I climb, I climb with my sisters on the Krš up, up. $"$

She says that everyone who wants can see these creatures. It is just a matter of will. Her 'special' days - when she has to submit herself to the will and the demands of these creatures - are three specific days of the Christian orthodox calendar: Epiphany (Bogojavljanje - Three King's Day), Palm Sunday (Cveti), and St. Peter's Day (Petrovdan). On 
every occasion she gets information from her sisters about when they are going to appear the next time.

\section{The fieldwork}

I arrived with my driver one day before Cveti. Although it was April, Easter Serbia is a mountainous region with a pretty cold climate with winters sometimes lasting until midMay. At our arrival to our accommodation, we found out that Ivanka's house is on a top of the mountain of on almost $400 \mathrm{~m}$ above sea level. We were also told that the asphalt-road ends in the center of the village and that there is only one muddy-road leading up to her house. It was obvious that we are not going to reach that isolated farmhouse with our citycar. We immediately went for Topolnica to meet Ivanka for the first time. There we found a local man who had a Lada-Niva, a russian 4WD vehicle and struck a deal to take us up to Ivanka's house that day and the next.

The road leading to Ivanka's solitary farm was indeed difficult: steep almost to $75^{\circ}$, muddy and bumpy. A driving distance which would took less than 10 minutes on flat asphalt, lasted almost half of an hour. Upon on arrival, I established an initial contact with Ivanka and she took me to 'her tree' on which she was initiated when she became a fairy-seer. We were told that we should be back at her house the next morning at 6AM on Palm Sunday.

\section{Methodology}

Being concerned that it was the last time Ivanka was 'falling' and I might never be able again to witness a trance of a 'šojmanka' I have planned to film and photograph each moment. My driver has become 'unoccupied' after our arrival in Topolnica, so I have asked him to record every moment of the event. Although my driver had the usual experience in filming (mainly using his mobile-phone), this turned out to be a tricky decision. We started filming as soon as we sat down in the Lada-Niva.

The ritual of trance started early in the morning in the break of down. The day of her 'fall' Ivanka frees herself from working in the stables with the animals of her farm -in order to stay clean. These creatures abhor filthy, unclean clothes, people and places. She also washes herself, avoids speaking (they defend her to speak before the ritual) and she dresses in light-colored clothes. She is holding three branched basil (Lat. Occimum basilicum) in her hand that she will keep on holding the whole time of her trance and consultation with people who came to see her that day. She also has to be 'clean' (not menstruating) as well as the women who attend the ritual or who come to consult her three sisters through her. Her husband related about cases when women were sent away because they were 'unclean'. The fall into trance lasts on different occasions differently: some days it can last an hour, but occasions when it lasted for four hours were also witnessed. Ivanka sings 'her' song outside in the court, dances, and shouts and calls her sisters invoking their coming and whistles in turns. She is transmitting to the present individuals, who sometimes come from other regions to consult the sojmanje, or the vlva-s (Vlach word 'fairy') -as these creatures are 
called. Ivanka transmits the feast-like atmosphere that precedes the coming of these creatures. She proceeds first by foretelling the future of the region, giving accounts of future accidents, future sudden deaths or forthcoming misfortunes or imminent great events in the country. For instance, in 2006 she predicted the coming of a president who is going to be as Tito.

When she is completely 'taken' - possessed - by her 'sisters' she asks to be taken into her house. The house hast to be clean, particularly a chair on which she will sit that day. A person, a woman, who comes that day as first (usually her neighbor) will help her to get back into the house. In her bedroom, sitting on a chair with her eyes closed she will receive one by one her visitors through the whole day. First, the consultation is 'about the living' ( $z a$ żive). Individuals or families can consult Ivanka's sisters through her mouth about their personal or family's future. When the consultation 'for the living' ends, there is another 'tour': one by one the individuals re-enter and consult Ivanka for their deceased relatives. This part is called 'for the dead' ( $z a$ mrtve). This time, flowers and candles have to be brought inn. The number of candles has to be the same as the number of dead of which wellbeing the person would like to enquire. Beside her sisters, Ivanka can see and talk with the deceased too. The dead send their request to their living: if they would like a visit to their graves, flowers, candles or a 'pomana' (a Vlach commemoration that includes bringing new clothes to the dead on their grave or brining favorite food and drink).

The helper of Ivanka was already present in the court although we have arrived almost sharp at 6h: it was her 'neighbor' from a nearby farm, 2-3 km from Ivanka's house, from another top of the mountain. The weather was cold, almost $0^{\circ} \mathrm{C}$ however Ivanka was singing, dancing her to a trance for almost 2 hours. At my surprise, about 20 people-visitors have arrived from all around the region in order to consults the vlva's. I was standing closer to Ivanka, intermittently filming and photographing. My driver was filming from a distance. Upon initial montage for a short documentary directed by me, the shortages of using an 'amateur' for recording of a unique scene became patent: my driver's hand was shaking, and one can hear occasionally clearly his sighs and heavy breathing... We have 'covered' the event most of the time: right until Ivanka fell into trance and was taken in the house where the visitors consulted her one by one. And it was my driver who filmed the scenes from inside of the house, while I had my own 'consultation' with the fairies. As it turned out: they brought a lot of messages from my deceased family members.

\section{References}

ČIČA, Zoran (2002) Vilenica i vilenjak, Sudbina jednog pretkršćanskog kulta u doba progona vještica. Zagreb: Etnografija.

Tomić, Persida (1950) Vilarke i vilari kod vlaškihCigana u Temniću i Belici. Zbornik Radova, SAN, Etnografski Institut. pp. 237-262. 
VIVOD | Recording the last trance | 5

about the author

Received on December $10^{\text {th }}, 2020$

Approved on December $20^{\text {th }}, 2020$ 

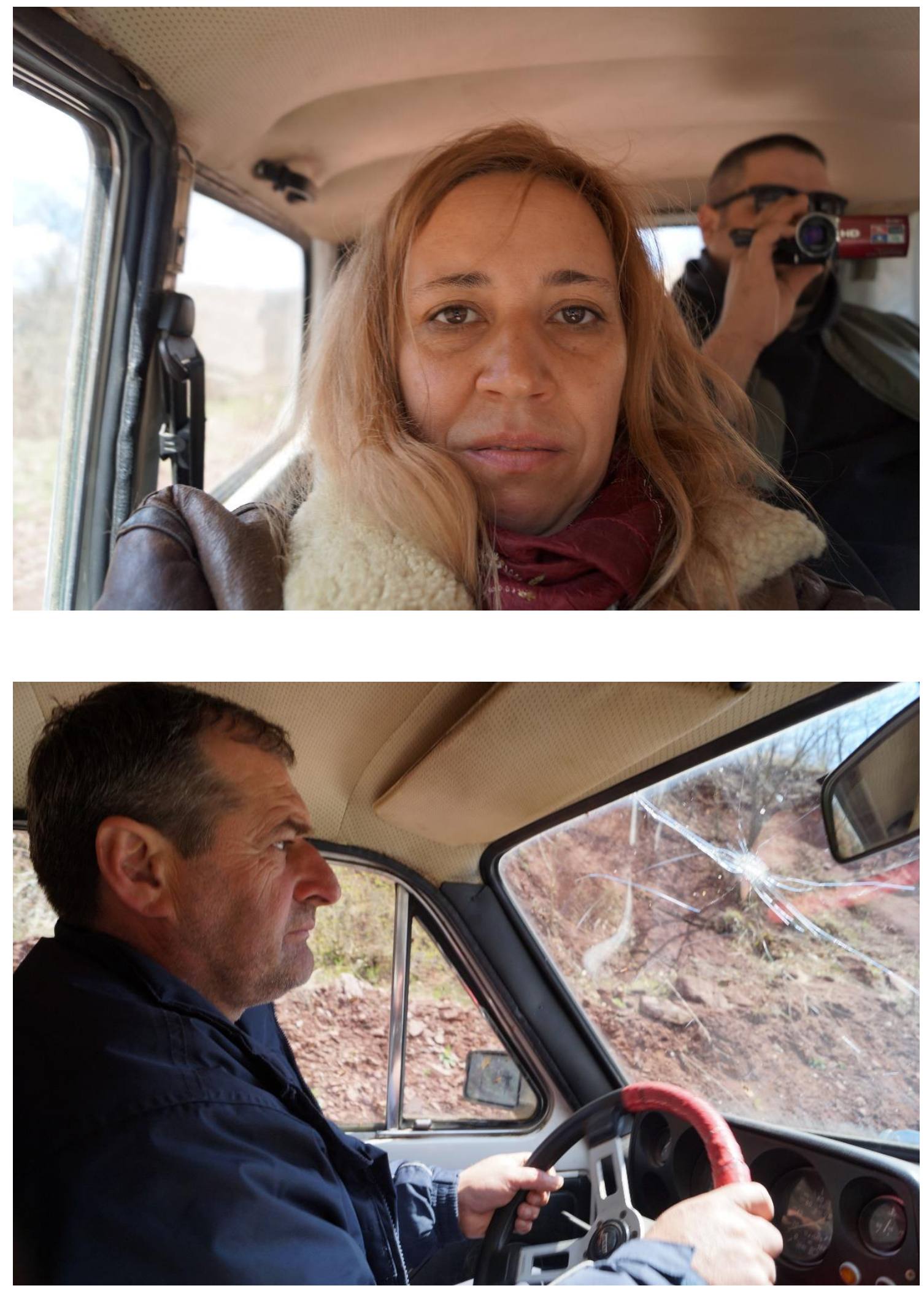
VIVOD | Recording the last trance $\mid 7$
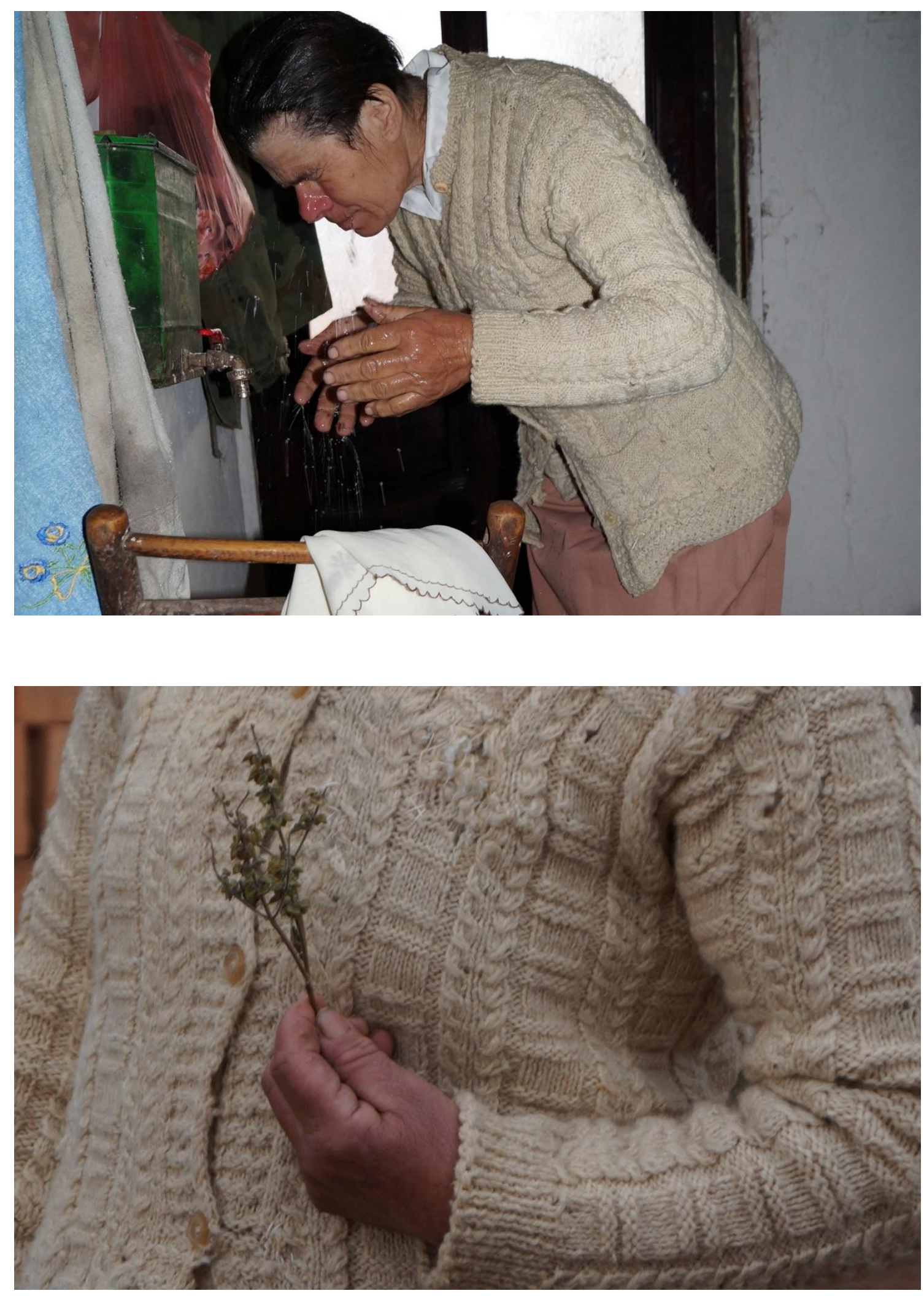
VIVOD | Recording the last trance | 9

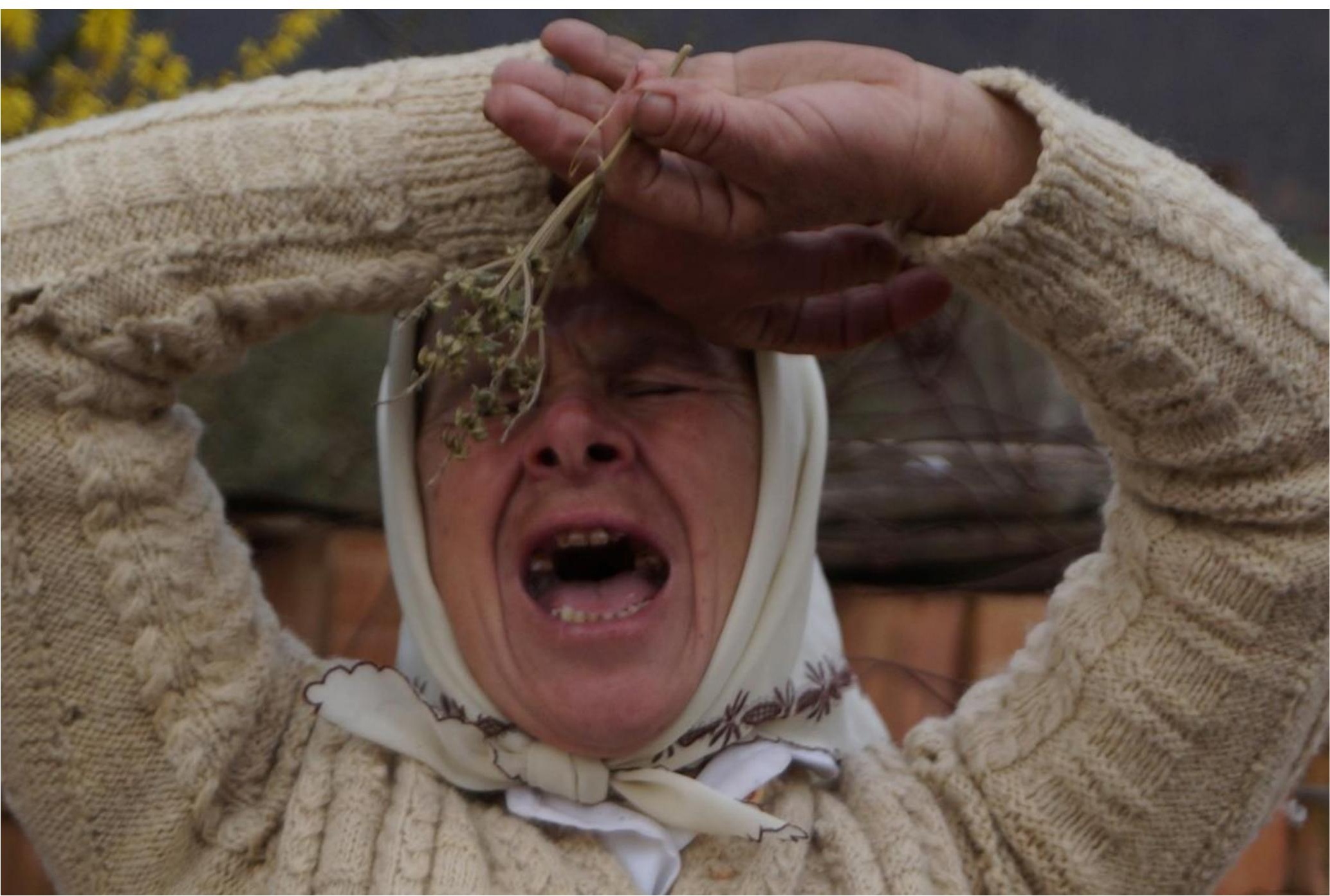


VIVOD | Recording the last trance | 10
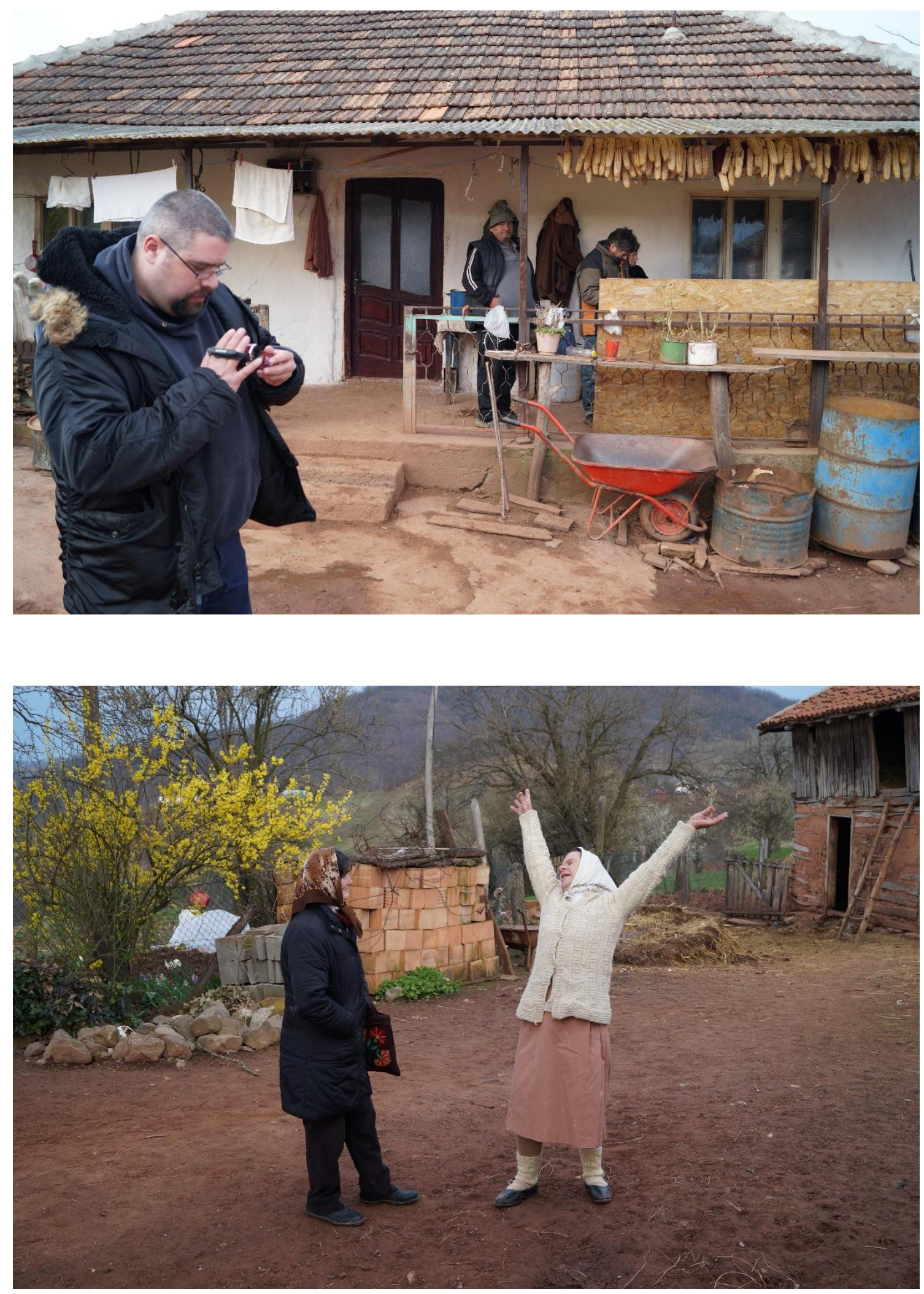

VIVOD | Recording the last trance | 12

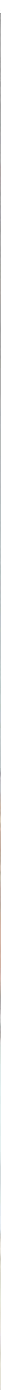


VIVOD | Recording the last trance | 13
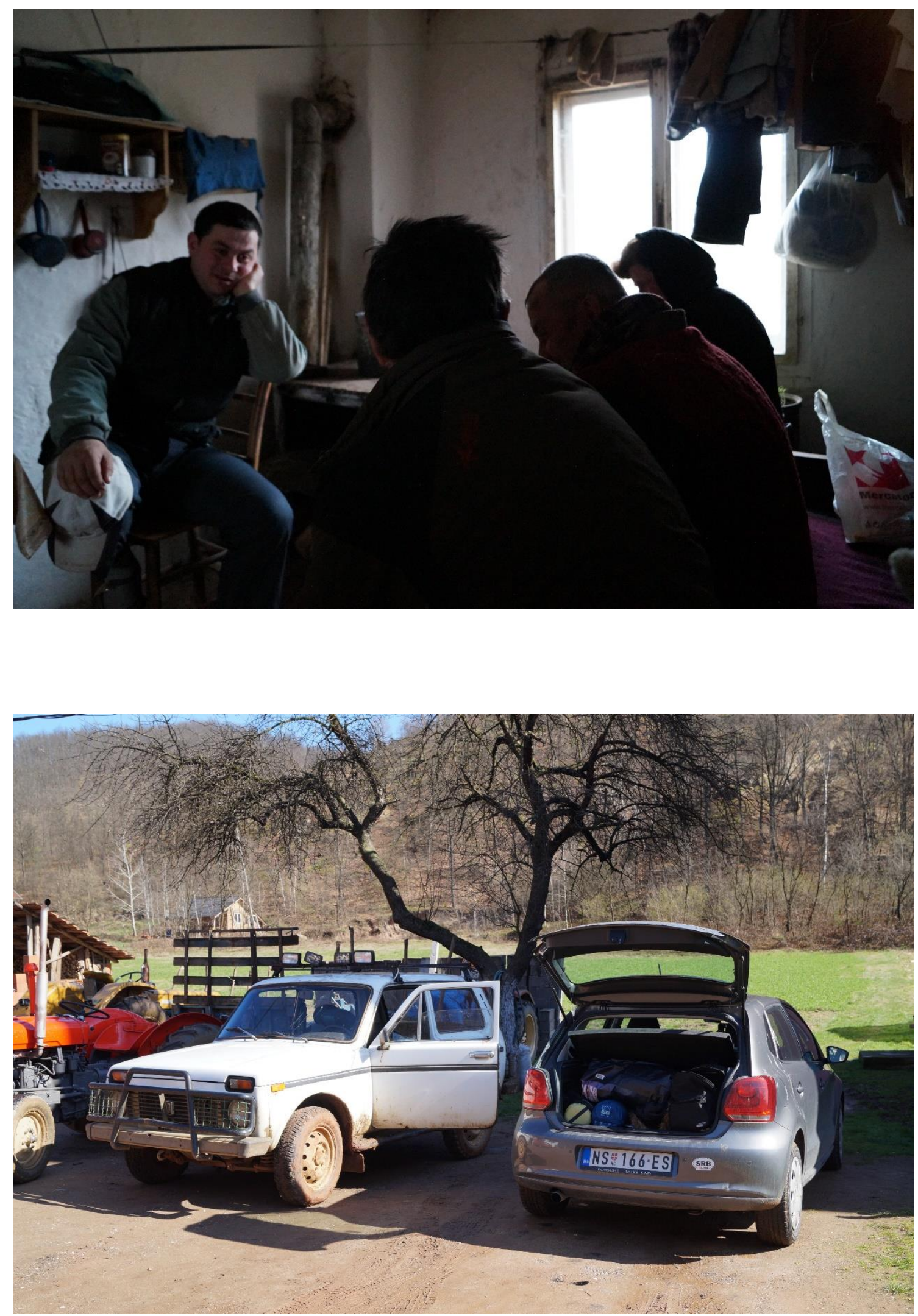